\title{
Empirical Regularities of Nigeria's Foreign Private Portfolio Investment Return and Volatility
}

\author{
Ihejirika Peters 0. PhD \\ Department of Banking and Finance, \\ Imo State University Owerri, Nigeria; \\ Michael Ndugbu PhD \\ Department of Banking and Finance, \\ Imo State University Owerri, Nigeria; \\ Ochiabuto Emeka \\ Department of Banking and Finance, \\ Imo State University Owerri, Nigeria;
}

\begin{abstract}
This paper examined the Empirical Regularities of Nigeria's Foreign Private Portfolio Investment Return and Volatility. The study covered the periods between 1981 and 2014. An EGARCH model was specified. The analysis involves carrying out the tests for Financial Assets and Risk assumptions. The study revealed that Foreign Private Portfolio Investment Returns show Volatility clustering. Secondly, Foreign Private Portfolio Investment Return and Risk were found to have Thick tail. Variance Ratio Test [VRT] was used to test the weak form efficiency of the efficient market hypothesis and hence the non-predictability of financial markets. The Results showed that changes in one direction are more often followed by similar changes in either direction (volatility clustering). Given that Nigeria's Foreign Private portfolio investment empirical imperatives is regular like that of the rest of the world, the paper thus recommends that investment decision models used by advanced analyst in developed countries can be applied to developing countries like Nigeria with little modification with respect to Foreign Private Portfolio Investment as their assets and risks display similar characteristics with assets and risks in developed countries.
\end{abstract}

Keywords: Empirical Regularities, Foreign Private Portfolio Investment Return and Volatility,

\section{INTRODUCTION}

In a paper titled "Principal Component analysis of Nigeria's Foreign Private Portfolio Investment (FPPI) volatility", Ndugbu, Ihejirika and Ochiabuto (2017) asserted that the decisive test to classify a purchase as investment is whether there is a "potential to turn return". The statement "potential to turn return" enfolds potential to turn losses. Succinctly, they inferred that investments are volatile.

Their study examined Foreign Investment Explicit Volatility and Volatility Theories and thus revealed that Foreign Private Portfolio Investment volatility proxy by ten key risks factors can be de - parameterized to Six (6) Principal components using the Kaiser's criterion and Cattell's scree test. These six components were selected as they were heavily affected by factors which are not common to all the other risks. The names of the extracted principal components were Taxability risk, Liquidity risk, Economic Risk, Political Risk, Commodity risk and Market risk.

The researchers admitted that the Principal Components have much implication and that these key Components can be used for further analysis. Hence, the objective of this paper is to use 
the Principal Components of Nigeria's Foreign Private Portfolio Investment volatility to examine the Empirical Regularities of Nigeria's Foreign Private Portfolio Investment Return and Volatility.

\section{Review of Concepts}

Foreign Investment

\section{REVIEW OF RELATED LITERATURE}

Foreign investment involves capital flows from one country to another, granting extensive ownership stakes in domestic companies and assets (Investopedia, 2016). Foreign investment is largely seen as a catalyst for economic growth. Foreign investments can be classified in one of two ways: direct and indirect. There are two additional types of foreign investments: commercial loans and official flows. Commercial loans are typically in the form of bank loans that are issued by a domestic bank to businesses in foreign countries or the governments of those countries. Official flow refers to different forms of developmental assistance to a developed or developing nation given by donor countries.

Foreign direct investment is investment made by a company or entity based in one country, into a company or entity based in another country. Entities making direct investments typically have a significant degree of influence and control over the company into which the investment is made. The accepted threshold for a foreign direct investment relationship, as defined by the Organization for Economic Co-operation and Development (OECD), is 10\% (OECD, 2008). The foreign investor must own at least $10 \%$ or more of the voting stock or ordinary shares of the investee company. Foreign portfolio investment (FPI) consists of securities and other financial assets passively held by foreign investors. FPI does not provide the investor with direct ownership of financial assets, and thus no direct management of a company. This type of investment is relatively liquid, depending on the volatility of the market invested in.

\section{Rate of Returns on International Investments}

Rate of return is profit on an investment over a period of time, expressed as a proportion of the original investment. A loss instead of a profit is described as a negative return. The time period is typically a year, in which case the rate of return is referred to as annual return. Return on investment (ROI) is return per naira invested. Ready Ratios (2016) explicate ROI as a performance measure used to evaluate the efficiency of investment. It is a measure of investment performance, as opposed to size (c.f. return on equity, return on assets, return on capital employed). The return or rate of return can be calculated over a single period, or where there is more than one time period, the return and rate of return over the overall period can be calculated, based upon the return within each sub-period.

\section{Empirical Regularities of Financial Asset Return and Volatility}

News in financial market can be seen from dimensions of non-trading periods, forecast able events and asymmetric effects. Non-trading period news refers to Information that accumulates when financial markets are closed as reflected in prices after the markets reopen. Fama (1965) and French and Roll (1986) found that information accumulates more slowly when the markets are closed than when they are open. Variances are higher following weekends and holidays than on other days, but not nearly by as much as would be expected if the news arrival rate were constant.

Forecast able events news refers to announcement effects. Forecast able releases of important information are associated with high ex ante volatility. For example, Cornell (1978) and Patell and Wolfson $(1979,1981)$ showed that individual firms' stock returns volatility is high around earnings announcements. Similarly, Harvey and Huang $(1991,1992)$ found that fixed income 
and foreign exchange volatility is higher during periods of heavy trading by central banks or when macroeconomic news is being released. For example, volatility is typically much higher at the open and close of stock trading than during the middle of the day. Trading and nontrading periods contribute differently to volatility.

The effect of good news and bad news may have asymmetric effects on volatility. In general when negative news hits a financial market, asset prices tend to enter a turbulent phase and volatility increases, but with positive news volatility tends to be small and the market enters a period of tranquility.

Leverage effect or asymmetric term first noted by Black (1976), refers to the tendency for changes in stock prices to be negatively correlated with changes in stock volatility. Fixed costs such as financial and operating leverage provide a partial explanation for this phenomenon. A firm with debt and equity outstanding typically becomes more highly leveraged when the value of the firm falls. This raises equity returns volatility if the returns on the firm as a whole are constant. Black (1976), however, argued that the response of stock volatility to the direction of returns is too large to be explained by leverage alone.

Amplitude of return as Mandelbrot (1963) wrote . . large changes tend to be followed by large changes, of either sign, and small changes tend to be followed by small changes.... Volatility clustering phenomenon is immediately apparent when asset return are plotted through time. The best known statistical model for the volatility-clustering phenomenon is the ARCH model (Robert M. Kunst and Johannes Kepler, 1997). According to Bo Sjö (2011) Volatility clusters mean that the variance appears to be high during certain periods and low in other periods.

"Persistence" of a shock to volatility: One perfectly reasonable definition of "persistence" would be to say that shocks fail to persist when shocks are stationary and ergodic. Nevertheless, apparent persistence of shocks may be driven by thick-tailed distributions rather than by inherent non-stationarity.

\section{Review of Theories}

\section{Foreign Investment Theories}

The Evolutionary Perspective

Views international investment as an ongoing, evolutionary process shaped by a Multinational Enterprise's (MNE's) international experience, organizational capabilities, strategic objectives, and environmental dynamics.

\section{The Integration-Responsiveness Perspective}

FDI is a complex process requiring coordinating subsidiary activities across national boundaries. Business people often talk about "thinking globally but acting locally." This theory establishes a framework. The framework, known as the global integration (I) and local responsiveness ( $R$ ) paradigm (or the I-R paradigm), suggests that participants in global industries develop competitive postures across two dimensions.

\section{Keynes investment theory}

Keynes' main contention was that investment is a function of the prospective marginal efficiency of capital relative to some interest rate which reflects the shadow cost of the invested funds. According to Keynes (1936), because of incomplete and uncertain information about private investment volatility in the future, potential investors would depend on their 
"animal spirits" in making their investment decisions rather than a rational calculation of an inherently intermediate distant future (Chete, 1998).

\section{Tobin's "Q" theory of investment of 1969}

This alternate formulation of the investment function postulates that the ratio of the market value of the existing stock of capital to its replacement cost (otherwise termed $Q$ ratio) is the force driving investment. This is a disequilibrium approach to investment. In this respect, investment is a function of both profitability and output demand considerations.

\section{The neoclassical theory}

The term "Neo-classical Theory" refers to work done in the eighteenth and nineteenth centuries by classical economists such as Adam Smith, David Ricardo, and Irving Fisher. The neoclassical theory argues that places that offer the highest rates of return will attract the most capital. The theoretical explanation offered at that time was the neoclassical capital arbitrage theory of portfolio flows. Based on assumptions of perfect competition, absence of transaction costs, and perfect information, the neoclassical theory explained international capital flows as responding to interest rate differentials (Williamson, 1985)

\section{The industrial organization approach}

In the 1960s, neoclassical theory was questioned because it did not distinguish foreign direct investments from portfolio investments. Hymer (1960) was among the first to see that FDI could not be coupled with portfolio investments. According to Hymer (1960), in order to analyze foreign investment, one must first analyze the multinational enterprise which thrives on market imperfections. Foreign firms face greater risks in making investments than do domestic firms because different and unfamiliar laws, different languages and cultures, and possible discrimination add to the costs of firms investing abroad. Therefore, MNCs must have some advantage over competitors or other reasons to invest directly in a foreign country.

\section{Research Design}

\section{RESEARCH METHODOLOGY}

The research follows a non-experimental design. The research is an ex post facto research. This means that relationships are investigated after the fact has been known. The variables needed were specified viz. Foreign Private Portfolio Investment Return and the Principal Component Risks.

\section{Sources of Data and Typology}

The Data typology is a time series Data. The sample size for the analysis was determined judgmentally. The researcher looks at a set of data covering a period of 34 years from 1981 2014. The data were sourced from a previous paper titled "Principal Component analysis of Nigeria's Foreign Private Portfolio Investment (FPPI) volatility” (Ndugbu et al, 2017)

\section{Tools of Analysis}

The Finometric model in question is the Exponential Generalized Autoregressive Conditional Heteroskedasticity (EGARCH) - in mean sector I given by equation (1) and (2):

$$
F P I_{R}=b_{0}+K \log \left(h_{t}\right)+b_{1} A A+e_{t} \ldots \ldots \ldots \ldots \ldots \ldots \ldots \ldots \ldots \ldots \ldots \ldots \ldots
$$

$\log \left(h_{t}\right)=w+a_{1}\left|e^{2}-1 / \delta_{t-1}\right|+b_{2} \log \left(h_{t-1}\right)+r e^{2}-1 / \delta_{t-1}+a_{2} C R_{t}+a_{3} P_{t}+a_{4} M R_{t}+a_{5} L_{t}+a_{6} R_{t}+a_{7} I_{t}$ $+a_{8} H_{t}+a_{9} L R_{t}+a_{10} F_{I R}+a_{11} K_{t}+a_{12} T_{t}+v_{t} \ldots \ldots \ldots \ldots \ldots . . .2$

The second equation is fine tuned to encompass the Principal Components as follows: 
$\log \left(\mathrm{h}_{\mathrm{t}}\right)=\mathrm{w}+\mathrm{a}_{1}\left|\mathrm{e}^{2} \mathrm{t}-1 / \delta_{\mathrm{t}-1}\right|+\mathrm{b}_{2} \log \left(\mathrm{h}_{\mathrm{t}-1}\right)+\mathrm{re}_{\mathrm{t}-1}^{2} / \delta_{\mathrm{t}-1}+\mathrm{a}_{2} \mathrm{TR}_{\mathrm{t}}+\mathrm{a}_{3} \mathrm{LR}_{\mathrm{t}}+\mathrm{a}_{4} \mathrm{ER}_{\mathrm{t}}+\mathrm{a}_{5} \mathrm{PR}_{\mathrm{t}}+\mathrm{a}_{6} \mathrm{CR}_{\mathrm{t}}+$ $\mathrm{a}_{7} \mathrm{MR}_{\mathrm{t}}+\mathrm{v}_{\mathrm{t}} \quad \ldots . . .3$

Where

r - Asymmetric or Leverage effect.

$\mathrm{FPPI}_{\mathrm{R}}-$ ForeignPrivate Portfolio Investment Returns.

AA - Asset Allocation. $\mathrm{K}$ - Risk - return tradeoff.

TR - Other Risk.

$\mathrm{e}_{\mathrm{t}}-$ Returns shock.

ER - Political Horizon Risk.

LR - Liquidity Exchange Rate Risk.

CR - Market Risk.

PR - Economic Longevity Risk.

$\mathrm{v}$ - Risk shock.

$\mathrm{h}_{\mathrm{t}^{-}}$Implied volatility.

MR - Market Ability Risk.

$\delta_{\mathrm{t}-1}$ - Lagged Standard error of Returns shock.

W - Average Return or Riskless Return.

GARCH-in-mean (GARCH-M) model provide three distinct specifications - one for the conditional mean equation, one for conditional variance, and one for conditional error distribution. The conditional variance is a function of three terms:

- a conditional term

- News about volatility from the previous period, measured by $\mathrm{e}^{2} \mathrm{t}-1$ (the ARCH term)

- Amplitude of return (the GARCH term)

\section{Time series assumptions:}

1. Variability in $\mathrm{X}$ values.

2. The construct is correctly specified.

3. $\mathrm{Y}$ and $\mathrm{X}$ are stationary random variables.

4. The errors are serially uncorrelated but not independent.

5. The number of observations $n$ must be greater than the number of parameters to be estimated.

\section{Empirical regularities of asset returns and risk}

1. Leptokurtic: they tend to be thick tails.

2. Volatility clustering: large changes tend to be followed by large changes of either sign.

3. Leverage effect: tendency for changes in stock prices to be negatively correlated with changes in volatility.

4. Non - trading period's effect: when a market is closed information seems to accumulate at a different rate to when it is open.

5. Forecast able events: volatility is high at regular times such as news announcements or other expected events.

6. Inverse relationship between volatility and serial correlation.

7. Co - movement in volatility: volatility is positively correlated across assets in a market and even across markets.

\section{Distributional assumptions}

1. Normal (Gaussian) assumption.

2. Student $t$ distribution has degrees of freedom which allow greater kurtosis\}.

3. Generalized error distribution (GED)

The objective of the paper is to test the empirical assumptions based on which Nigeria's Foreign Private Portfolio Investment Risk - Return is modeled. Hence, the tool of analysis involves carrying out the tests for these assumptions. 


\section{Data Presentation}

\section{DATA PRESENTATION AND ANALYSIS}

The table array of variables needed for this analysis is presented in Appendix E.

\section{Stationarity}

A time series is not stationary if it has the following features:

- If it has time varying mean.

- Or if it has time varying volatility.

- Or both.

A time series is strictly stationary if all the moments of its probability distribution and not just the first two (mean and variance) are invariant overtime. Here focus is on weak stationarity.

The Kwiatkowski - Phillips - Schmidt - Shin (KPSS) test is used to test for time varying mean, while Brock, Dechert, Scheinkman and LeBaron (BDS) test is used to check for time varying variance. The KPSS test for mean stationarity is laid out in the table below. The KPSS test shows that the variables are stationary I (0) in mean, while the BDS and variance ratio test (VRT) test conducted later indicates that the variables are not stationary in variance. This implies that we can study the series behavior beyond the time period under consideration. Each set of time series will not be for a particular episode. As a consequence, it is possible to generalize it to other time periods.

Table 1: Unit root test with the KPSS statistic

\begin{tabular}{|l|c|c|}
\hline Variable & Level of integration & Observed level of significance at 10\% \\
\hline Returnoninvestment & I (0) & 0.333908 \\
\hline Commodity risk & I (0) & 0.124545 \\
\hline Market risk & I (0) & 0.108098 \\
\hline Liquidity risk & I (0) & 0.255366 \\
\hline Political risk & I (0) & 0.307143 \\
\hline Taxability risk & I (0) & 0.263823 \\
\hline Economic risk & I (0) & 0.762668 \\
\hline Mygarch & I (0) & 0.46745 \\
\hline
\end{tabular}

\section{Source: Eview output}

\section{Empirical Regularities of Financial Asset Return and Volatility Amplitude of Return}

Volatility clustering means that there are periods when large changes are followed by further large changes and periods when small changes are followed by further small changes. Volatility clustering implies that the residuals are serially uncorrelated, but not independent. Being serially uncorrelated, but not independent implies that the residuals are strict white noise. The aim is to look at the heteroscedastic random walk. Serially uncorrelated simply means the series are random walk (white noise). White noise process hovers around zero. A white noise series is probably stationary. One popular approach to answering the question of serially uncorrelated is the Lo and MacKinlay overlapping variance ratio test. The variance ratio test examines the predictability of time series data by comparing variances of differences of the data (returns) calculated over different intervals. Alternately, Lo and MacKinlay outline a heteroskedastic random walk hypothesis where they weaken the independent and identically distributed (i.i.d.) assumption and allow for fairly general forms of conditional 
heteroskedasticity and dependence. This hypothesis is sometimes termed the martingale null, since it offers a set of necessary (but not sufficient), conditions for $\epsilon_{\mathrm{t}}$ to be a martingale difference sequence (m.d.s.). The EGARCH - IN mean residuals is a random walk or follows the martingale difference as the Chow Denning Maximum $|z|$ statistic observed significance of 0.5667 (see appendix A) accepts the null hypothesis. Thus conclude that the residual are serially uncorrelated and dependent.

The other side of volatility clustering is that apart from being serially uncorrelated, the residuals are not independent. A test to check for independence is the BDS (Brock, Dechert, Scheinkman and LeBaron) test. The BDS test is a portmanteau test for time based dependence in a series. The test can be applied to a series of estimated residuals to check whether the residuals are independent and identically distributed (iid). The dimensions of the BDS reject the hypothesis of i.i.d and conclude that observations of the residuals are not independent.

Volatility clustering can also be tested by conducting test for strict white noise. The Ljung-Box $Q$-statistics (see appendix B) for high-order serial correlation is often used as a test of whether the series is white noise. The $Q$-statistic at lag k is a test statistic for the null hypothesis that there is no autocorrelation up to order $\mathrm{k}$ (that is are white noise). The $\mathrm{Q}$ - statistics are insignificant correlations at all lags, thus the result indicates volatility clustering. This is because all the standardized residuals are white noise. Another test for volatility clustering is the test for ARCH effect performed in section 4.3.4.

\section{Thick Tails}

Thick Tails means that asset returns and risks tend to be leptokurtic. To model the thick tail in the residuals, we will assume that the errors follow a Student's $t$-distribution. The T-DIST. DOF of the EGARCH - IN MEAN output shows that the distribution of the standardized errors departs significantly from normality with a probability value of 0.0000 . Given that the white noise (standardized errors) has different distribution (Jarque-Bera observed level of 0.000000 rejects the normality assumption) than normal, then white noise inherits a non - vanishing skewness (3.233367). The kurtosis shows that the white noise has thick tail (17).
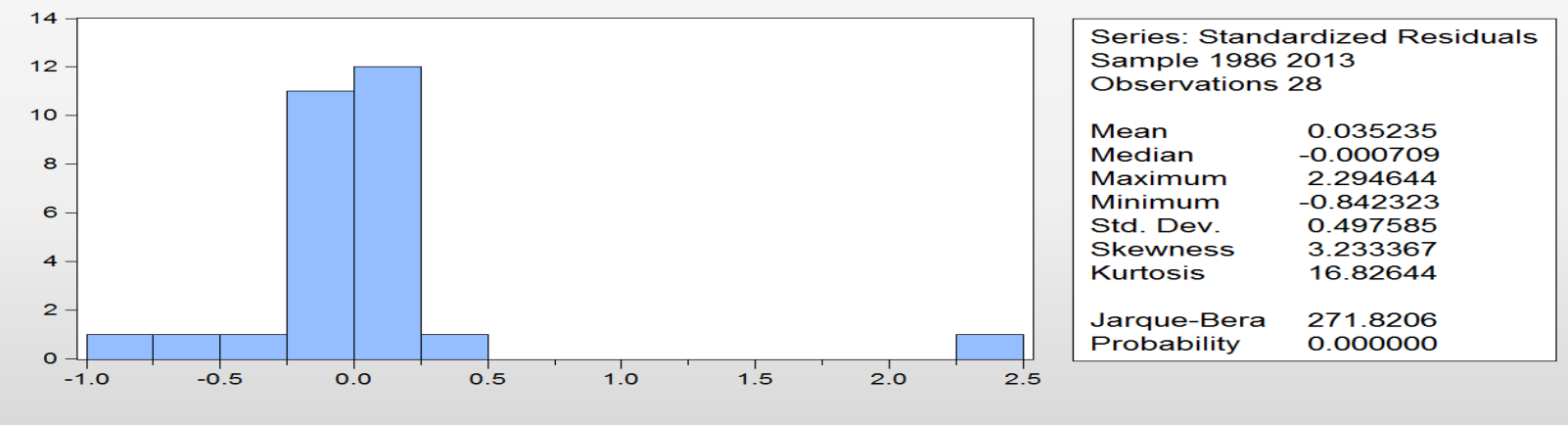

Figure A: Standardized residuals characteristics 


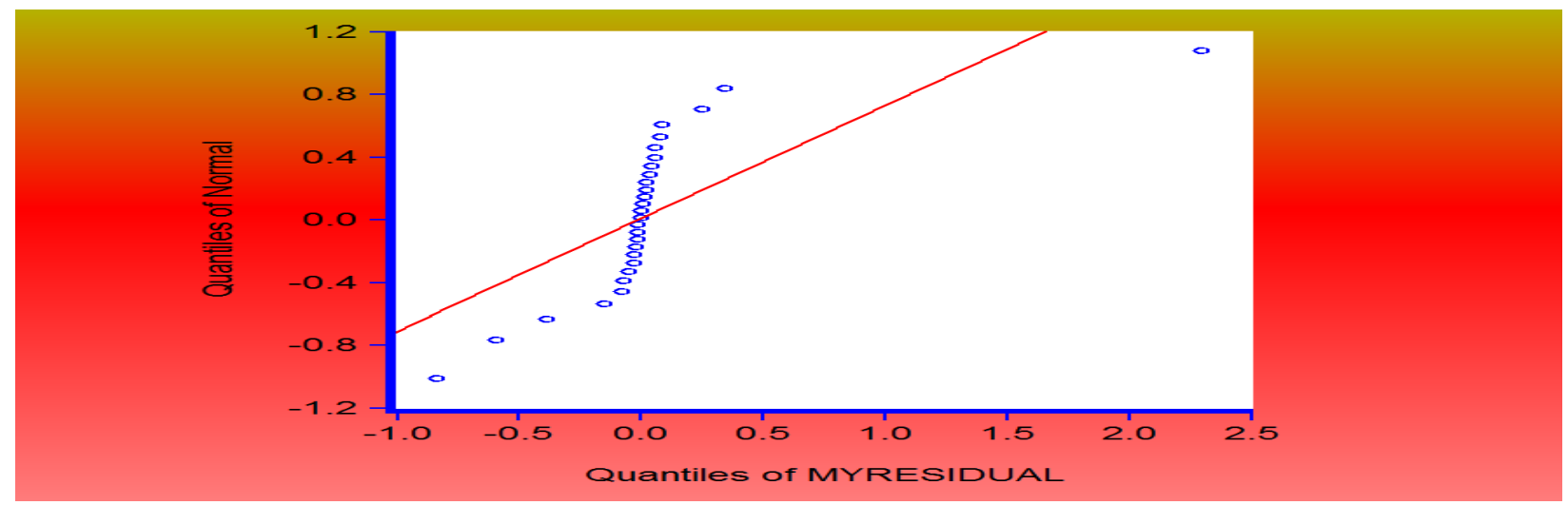

Figure B: Standardized residual Q - Q statistic

Similarly, the Jarque-Bera (JB) statistic observed level 0.139097 indicates that the returns are normally distributed, while the kurtosis value of 4 shows that asset returns are leptokurtic. The plot of Q-Q theoretical in figure B above indicates that it is primarily large negative shocks that are driving the departure from normality

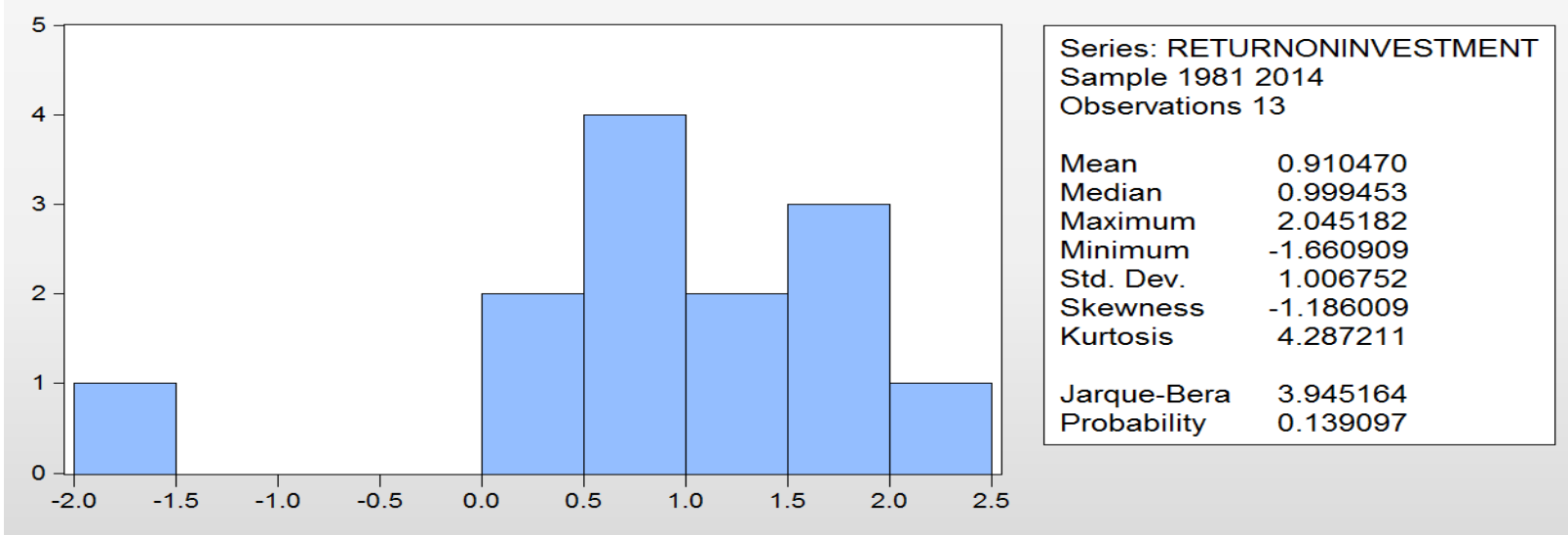

Figure C: Return on investment characteristics

\section{Mean Reversion and Forecast able Events}

Mean reversion apply the idea of buy low sell high. Mean reversion is measured with the variance ratio test (VRT). The variance ratio test measures trendiness or degree of mean reversion in a price or return of a series. VRT also tests the weak form efficiency of the efficient market hypothesis and hence the non-predictability of financial markets (see Ihejirika and Anyanwu 2013).

Variance ratio equal to one indicates that returns are pure random walk. Hence, no predictions are possible and hence trial to create a profitable trading system on such a return will fail. A variance ratio value greater than one indicates that returns show tendency to form trends. This means that changes in one direction are more often followed by similar changes in either direction (volatility clustering). Variance ratio less than one indicate that returns show some degree of mean reversion. This means that changes in one direction are followed by changes in the opposite direction.

The returns show volatility clustering using the variance ratio statistic and graph. 


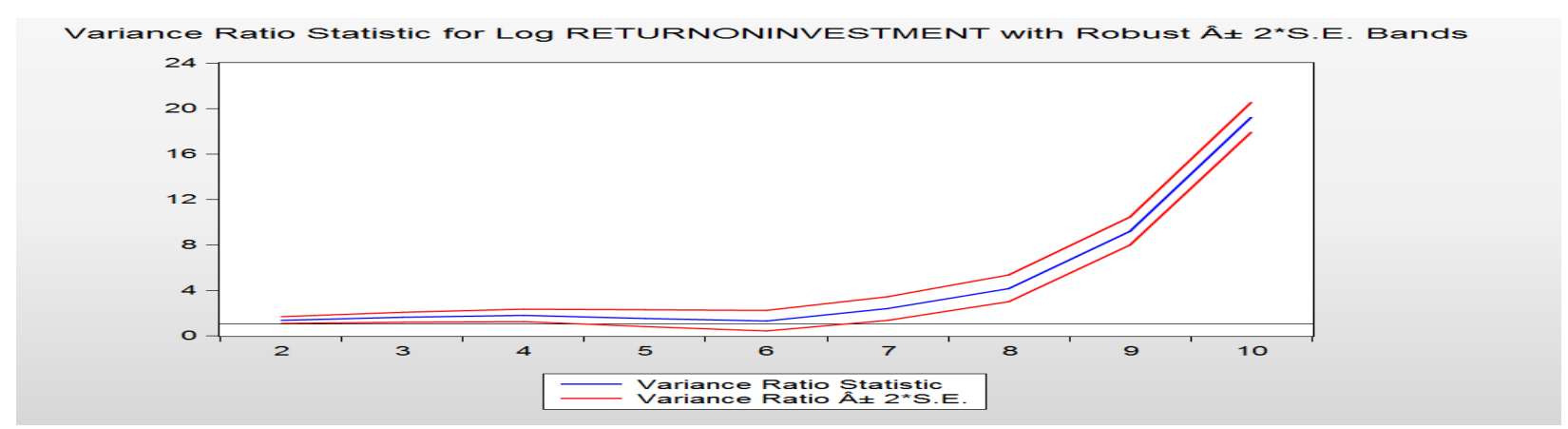

Figure D: Variance ratio graph

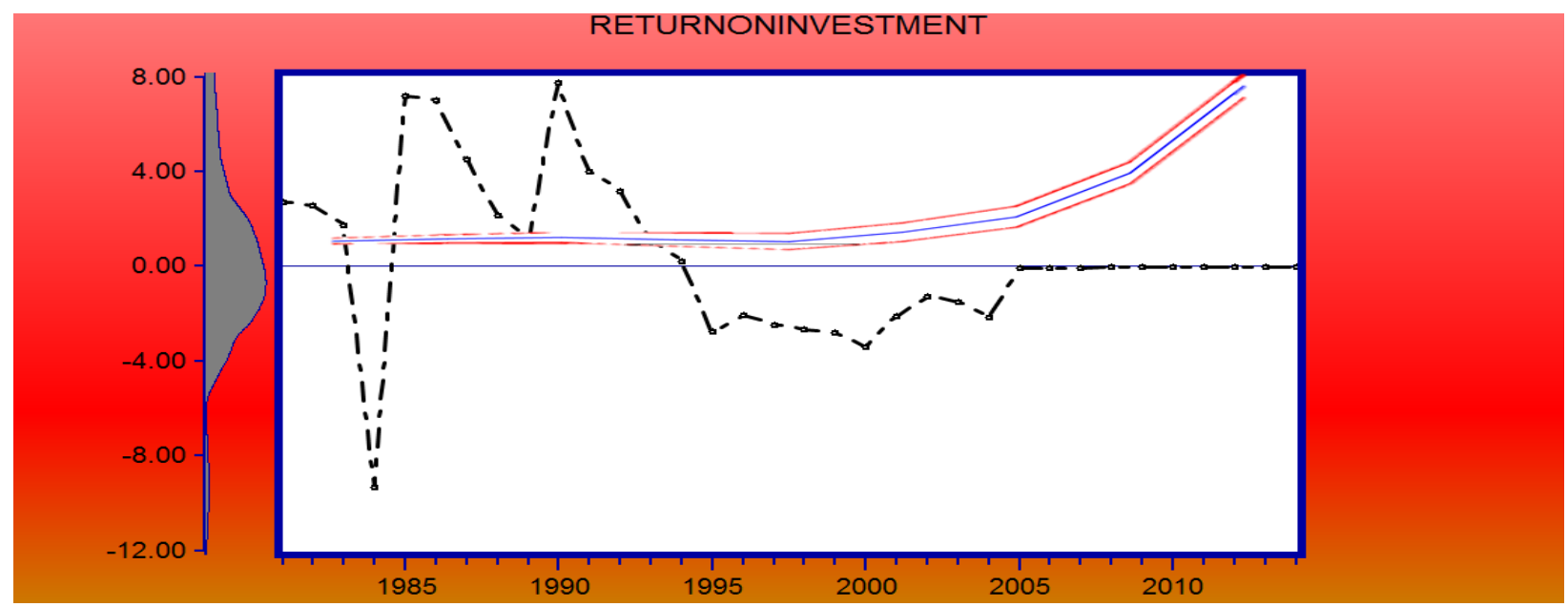

Figure E: graph of return on investment and variance ratio

\section{Arch Effect (Time Varying Volatility)}

The LaGrange multiplier test $\mathrm{F}$ statistic observed level of 0.7641 indicates no evidence of remaining ARCH (see appendix C)

\section{DISCUSSION OF FINDINGS}

The study revealed that Returns show Volatility clustering. This implies Investment Returns residuals are strict white noise. Foreign Private Portfolio Investment Return and Risk were found to have Thick tail. This implies that Foreign Private Portfolio Investment Return and Risk tend to be leptokurtic.

Mean reversion apply the idea of buy low sell high. The Variance Ratio Test (VRT) was used to test this as well as the weak form efficiency of the efficient market hypothesis and hence the non-predictability of financial markets. The results show volatility clustering using the variance ratio statistic and graph. This means that changes in one direction are more often followed by changes in the same direction.

\section{CONCLUSION}

This paper used the Principal Components of Nigeria's Foreign Private Portfolio Investment volatility to examine the Empirical Regularities of Nigeria's Foreign Private Portfolio Investment Return and Volatility. The study concludes that Nigeria's Foreign Private portfolio investment empirical imperatives is regular like that of the rest of the world. Based on the above findings the study recommends that investment decision models used by advanced analyst in developed countries can be applied to developing countries like Nigeria With little modification with respect to Foreign Private Portfolio Investment as their Assets and Risks display similar characteristics with Assets and Risks in Developed countries. 


\section{References}

Black, F. (1976). Studies of stock price volatility changes. Proceedings from the American statistical association, business and economic statistics section, 177-181.

Bo Sjö (2011) Modelling the Volatility of the Electrolux Stock. Estimation and testing for arch and garch (Revised January 6, 2011).

Chete, L. N. (1998). Determinants of Foreign Direct Investments in Nigeria. Society for economic research monograph series, 7, 289-336.

Cornell, B. (1978). Using the options pricing model to measure the uncertainty producing effect of major announcements. Financial Management, 7, 54 - 59.

Fama, E.F. (1965). The Behavior of Stock Market Prices. Journal of Business 3, 8, 34b105.

French, K.R., \& Roll, R. (1986). Stock return variances: The arrival of information and the reaction of traders. Journal of Financial Economics, 17, 5-26.

Harvey, C.R., \& Huang, R.D. (1991). Volatility in the foreign currency futures market. Review of financial studies, 4, 543-569.

Harvey, C.R., \& Huang, R.D. (1992). Information trading and fixed income volatility, Unpublished manuscript, Department of finance, Duke University.

Hymer, S. (1960). The international operations of nation firms: A study of foreign direct investment.

Cambridge, MLT Press. (1960 dissertation) Investopedia http://www.investopedia.com/terms/p/portfolioinvestment.asp

Ihejirika, P. O and Anyanwu G (2013) Characterization of Volatilities in the Nigerian Stock Exchange: Prospects for Options Trading International Institute for Science, Technology \& Education Research Journal of Finance and Accounting Vol.4, No.16. 38-49

Keynes, J.M. (1936). The General Theory of Employment, Interest and Money. Volume III of the collected writings of John Maynard Keynes, London: McMillan.

Mandelbrot, B. (1963). The Variation of Certain Speculative Prices. Journal of Business, 36, 394-419

OECD (2008). OECD benchmark definition of Foreign Direct Investment. Fourth Edition 2008

Patell, J.M., \&Wolfson, M.A. (1979). Anticipated information releases reflected in call option prices. Journal of accounting and economics, 1, 117-140.

Patell, J.M. \& Wolfson, M.A. (1981). The ex-ante and ex-post price effects of quarterly earnings announcement reflected in option and stock price. Journal of Accounting Research, 19, 434-458.

ReadyRatios (2016). http://www.readyratios.com/ reference/profitability/return_on_investment_roi.html.

Robert, M., \&Kunst, J. K (1997). Augmented arch models for financial time series: stability conditions and empirical evidence. Institute for advanced studies Stumpergasse 56, A-1060 Vienna, Austria. Applied financial economics, 1997, 7, 575-586.

Williamson, O.E. (1985). The economic institutions of capitalism. Free Press: New York. 


\section{Appendix A: Variance ratio test}

\section{APPENDIX}

Null Hypothesis: MEANRESIDUAL is a martingale

Date: 10/19/16 Time: 04:17

Sample: 19812014

Included observations: 27 (after adjustments)

Heteroskedasticity robust standard error estimates

Use biased variance estimates

User-specified lags: 24816

\begin{tabular}{cccc}
\hline \hline Joint Tests & Value & df & Probability \\
\hline Max $|\mathrm{z}|($ at period 4)* & 1.314511 & 27 & 0.5667 \\
\hline
\end{tabular}

Individual Tests

\begin{tabular}{ccccc} 
Period & Var. Ratio & Std. Error & z-Statistic & Probability \\
\hline 2 & 0.481958 & 0.398679 & -1.299395 & 0.1938 \\
4 & 0.212082 & 0.599400 & -1.314511 & 0.1887 \\
8 & 0.068730 & 0.740442 & -1.257721 & 0.2085 \\
16 & 0.026046 & 0.879408 & -1.107511 & 0.2681 \\
\hline \hline
\end{tabular}

*Probability approximation using studentized maximum modulus with

parameter value 4 and infinite degrees of freedom

Test Details (Mean $=-0.0119518900946)$

\begin{tabular}{cccc}
\hline \hline Period & Variance & Var. Ratio & Obs. \\
\hline 1 & 0.50740 & -- & 27 \\
2 & 0.24454 & 0.48196 & 26 \\
4 & 0.10761 & 0.21208 & 24 \\
8 & 0.03487 & 0.06873 & 20 \\
16 & 0.01322 & 0.02605 & 12 \\
\hline \hline
\end{tabular}

Null Hypothesis: Log RETURNONINVESTMENT is a martingale Date: 10/19/16 Time: 05:24

Sample: 19812014

Included observations: 11 (after adjustments)

Heteroskedasticity robust standard error estimates

Lags specified as grid: $\min =2$, $\max =10$, step $=1$

\begin{tabular}{cccc}
\hline \hline Joint Tests & Value & df & Probability \\
\hline Max $|\mathrm{z}|$ (at period 10)* & 27.63640 & 11 & 0.0000 \\
\hline
\end{tabular}

Individual Tests

\begin{tabular}{ccccc} 
Period & Var. Ratio & Std. Error & z-Statistic & Probability \\
\hline 2 & 1.359774 & 0.158324 & 2.272389 & 0.0231 \\
3 & 1.629494 & 0.225187 & 2.795422 & 0.0052 \\
4 & 1.776950 & 0.282565 & 2.749628 & 0.0060 \\
5 & 1.518257 & 0.367090 & 1.411797 & 0.1580
\end{tabular}




$\begin{array}{ccccc}6 & 1.305822 & 0.453209 & 0.674792 & 0.4998 \\ 7 & 2.367640 & 0.522629 & 2.616848 & 0.0089 \\ 8 & 4.161073 & 0.577707 & 5.471761 & 0.0000 \\ 9 & 9.193746 & 0.622345 & 13.16591 & 0.0000 \\ 10 & 19.22092 & 0.659309 & 27.63640 & 0.0000\end{array}$

*Probability approximation using studentized maximum modulus with

parameter value 9 and infinite degrees of freedom

Test Details (Mean $=-0.371199369234)$

\begin{tabular}{cccc}
\hline \hline Period & Variance & Var. Ratio & Obs. \\
\hline 1 & 0.81718 & -- & 11 \\
2 & 1.11118 & 1.35977 & 10 \\
3 & 1.33159 & 1.62949 & 9 \\
4 & 1.45208 & 1.77695 & 9 \\
5 & 1.24069 & 1.51826 & 8 \\
6 & 1.06709 & 1.30582 & 7 \\
7 & 1.93478 & 2.36764 & 6 \\
8 & 3.40034 & 4.16107 & 5 \\
9 & 7.51292 & 9.19375 & 4 \\
10 & 15.7069 & 19.2209 & 3 \\
\hline \hline
\end{tabular}

\section{Appendix B: Ljung - Box Q statistic}

Date: 10/19/16 Time: 03:46

Sample: 19812014

Included observations: 28

Q-statistic probabilities adjusted for 1 dynamic regressor

\begin{tabular}{|c|c|c|c|c|c|}
\hline Autocorrelation & $\begin{array}{c}\text { Partial } \\
\text { Correlation }\end{array}$ & $\mathrm{AC}$ & PAC & Q-Stat & Prob* \\
\hline .1 .1 & .1 .1 & $1-0.029$ & -0.029 & 0.0266 & 0.870 \\
\hline .1 .1 & .1 .1 & 20.007 & 0.007 & 0.0284 & 0.986 \\
\hline .1 .1 & .1 .1 & 30.002 & 0.002 & 0.0285 & 0.999 \\
\hline$.\left.\right|^{*} . \mid$ & $.1^{*} . \mid$ & 40.127 & 0.127 & 0.5929 & 0.964 \\
\hline$*^{* *}||$. & $*^{* *}|\cdot|$ & $5-0.247$ & -0.244 & 2.8167 & 0.728 \\
\hline$\cdot 1 \cdot 1$ & $.1 \cdot 1$ & 60.004 & -0.005 & 2.8172 & 0.831 \\
\hline $.1 \cdot 1$ & .1. & $7-0.020$ & -0.019 & 2.8331 & 0.900 \\
\hline .1 .1 & .1 .1 & 80.027 & 0.015 & 2.8628 & 0.943 \\
\hline $.1 \cdot 1$ & $\cdot 1^{*} \cdot \mid$ & 90.025 & 0.093 & 2.8903 & 0.968 \\
\hline$*^{* *}|\cdot|$ & $*^{* *}|\cdot|$ & $10-0.243$ & -0.330 & 5.6348 & 0.845 \\
\hline $.1 \cdot 1$ & .1 .1 & $11-0.022$ & -0.012 & 5.6590 & 0.895 \\
\hline .1 .1 &.$i \cdot i$ & 120.015 & 0.005 & 5.6706 & 0.932 \\
\hline
\end{tabular}




\section{Appendix C: Langrange multiplier test}

Heteroskedasticity Test: ARCH

\begin{tabular}{llll}
\hline \hline F-statistic & 0.092063 & Prob. F(1,25) & 0.7641 \\
Obs*R-squared & 0.099063 & Prob. Chi-Square(1) & 0.7530 \\
\hline \hline
\end{tabular}

Test Equation:

Dependent Variable: WGT_RESID ${ }^{\wedge} 2$

Method: Least Squares

Date: 10/18/16 Time: 06:53

Sample (adjusted): 19872013

Included observations: 27 after adjustments

\begin{tabular}{lrlll}
\hline \hline \multicolumn{1}{c}{ Variable } & Coefficien & & & \\
\multicolumn{1}{c}{ C } & $\mathrm{t}$ & Std. Error & t-Statistic & Prob. \\
\hline \hline WGT_RESID^2(-1) & 0.261676 & 0.204812 & 1.277642 & 0.2131 \\
\hline \hline & 0.060599 & 0.199722 & -0.303418 & 0.7641 \\
\hline R-squared & 0.003669 & Mean dependent var & 0.246607 \\
Adjusted & R- & & & \\
squared & -0.036184 & S.D. dependent var & 1.014282 \\
S.E. of regression & 1.032470 & Akaike info criterion & 2.972971 \\
Sum squared resid & 26.64983 & Schwarz criterion & 3.068959 \\
Log likelihood & -38.13511 & Hannan-Quinn criter. 3.001514 \\
F-statistic & 0.092063 & Durbin-Watson stat & 2.006718 \\
Prob(F-statistic) & 0.764082 & & \\
\hline \hline
\end{tabular}




\section{Appendix D: Correlogram squared residuals}

Date: 10/19/16 Time: 15:20

Sample: 19812014

Included observations: 28

\begin{tabular}{ccrrr}
\hline \hline & $\begin{array}{c}\text { Partial } \\
\text { Autocorrelation } \\
\text { Correlation }\end{array}$ & AC & PAC & Q-Stat \\
\hline \hline I. Prob*
\end{tabular}

*Probabilities may not be valid for this equation specification. 
APPENDIX E

Table1: Cell array of the principal component risks

\begin{tabular}{|c|c|c|c|c|c|c|}
\hline YEAR & $\begin{array}{c}\text { TAXABILITY } \\
\text { RISK } \\
\end{array}$ & $\begin{array}{c}\text { LIQUIDITY } \\
\text { RISK } \\
\end{array}$ & $\begin{array}{c}\text { ECONOMIC } \\
\text { RISK } \\
\end{array}$ & $\begin{array}{c}\text { POLITICAL } \\
\text { RISK } \\
\end{array}$ & $\begin{array}{c}\text { COMMODITY } \\
\text { RISK }\end{array}$ & $\begin{array}{l}\text { MARKET } \\
\text { RISK }\end{array}$ \\
\hline 1981 & NA & NA & NA & NA & NA & NA \\
\hline 1982 & -1.287362 & -0.54043 & -1.72633 & -3.09946 & -1.59839 & -0.36905 \\
\hline 1983 & -0.234714 & 0.059317 & -1.56481 & -2.01706 & -0.58422 & -0.44029 \\
\hline 1984 & 0.160926 & 0.058752 & -1.07884 & -0.96249 & -0.57641 & -0.04561 \\
\hline 1985 & -0.708898 & -0.5568 & -0.38287 & -0.44021 & -0.38835 & 0.079286 \\
\hline 1986 & -1.100047 & -0.18001 & -0.01409 & -0.36647 & 0.132203 & 0.025998 \\
\hline 1987 & 0.341295 & 0.397972 & -0.61174 & -0.24051 & 0.281479 & -0.97795 \\
\hline 1988 & 1.405822 & -0.74948 & -0.60471 & -1.17059 & 0.729271 & -0.36155 \\
\hline 1989 & 0.100069 & -0.132 & -0.73887 & -0.23989 & -0.06469 & -0.21831 \\
\hline 1990 & 1.003987 & -1.31958 & 0.237017 & -0.50013 & 0.601952 & -0.40547 \\
\hline 1991 & 0.377801 & -2.35379 & 0.583389 & 0.806474 & -0.39172 & 0.200879 \\
\hline 1992 & 0.764743 & 0.09145 & -0.71135 & -0.75423 & 0.56374 & -0.63932 \\
\hline 1993 & -0.18949 & 0.732523 & -1.38445 & 1.2666 & 0.65538 & 0.86087 \\
\hline 1994 & -0.174356 & 0.895389 & -2.81538 & 1.380854 & 0.965991 & 1.179281 \\
\hline 1995 & 2.793582 & 4.108904 & -0.89368 & 0.583524 & 0.345773 & 2.590952 \\
\hline 1996 & 6.433625 & -2.60076 & 1.818112 & -0.81019 & 0.787195 & 0.897761 \\
\hline 1997 & 0.221517 & -1.63657 & 0.052576 & 1.075546 & 0.054107 & -0.09598 \\
\hline 1998 & -1.049415 & -1.94369 & -0.69729 & 2.875814 & 0.01294 & -0.11306 \\
\hline 1999 & -0.937469 & -1.41855 & -0.69889 & 2.469624 & 0.04057 & -0.3753 \\
\hline 2000 & 0.213552 & -0.29041 & -0.54171 & 0.062356 & -0.00417 & -0.16026 \\
\hline 2001 & 1.181952 & 1.583117 & 2.554715 & 1.382464 & -3.4824 & -0.53993 \\
\hline 2002 & 0.315594 & 1.336058 & 0.631184 & 0.376442 & -1.81282 & -1.36655 \\
\hline 2003 & -0.716947 & -0.29152 & -0.20025 & 0.071518 & -0.15477 & -0.04027 \\
\hline 2004 & -0.528171 & -0.78359 & -0.01582 & 0.196094 & -0.21974 & 0.19726 \\
\hline 2005 & 1.238905 & 1.527031 & 0.146404 & 0.005847 & -0.40879 & 0.159978 \\
\hline 2006 & -0.079888 & -0.12871 & -0.73328 & -0.10915 & 0.059789 & -0.11393 \\
\hline 2007 & -0.977566 & 0.000315 & 0.206931 & -0.07683 & -0.33092 & 0.53849 \\
\hline 2008 & -1.499516 & 0.135709 & 0.960551 & -0.2368 & 0.723454 & 0.216345 \\
\hline 2009 & -2.399554 & 0.614129 & 2.75926 & -0.73387 & 2.570088 & 0.524738 \\
\hline 2010 & 1.111552 & 2.255397 & 0.377498 & 0.261564 & 1.547876 & -3.00517 \\
\hline 2011 & -1.06097 & 1.151042 & 1.578838 & 0.210968 & 1.695399 & -1.793 \\
\hline 2012 & -0.901421 & -0.12918 & -0.08116 & -0.00957 & -0.7274 & 0.106293 \\
\hline 2013 & -2.319558 & -0.01727 & 1.833828 & -1.07234 & 0.17253 & 2.510201 \\
\hline
\end{tabular}

Source: Authors computations (factor scores from principal component analysis, Ndugbu et al

(2017) 